\title{
Hydrological response of a headwater catchment in southeastern Brazil Part I: Patterns of rainfall-runoff and stormflow
}

\author{
Mariane Chittolina ${ }^{1}$, Leonardo Dominques ${ }^{2}$, Gré de Araújo Lobo $^{3}$, and Humberto Rocha ${ }^{1}$ \\ ${ }^{1}$ Universidade de Sao Paulo Instituto de Energia e Ambiente \\ ${ }^{2}$ Universidade de Sao Paulo Instituto de Astronomia Geofisica e Ciencias Atmosfericas \\ ${ }^{3}$ Departamento de Águas e Energia Elétrica - Centro Tecnológico de Hidráulica e Recursos \\ Hídricos (DAEE-CTH) Professor Lúcio Martins Rodrigues Avenue 120 CEP 05508-020 \\ University City - São Paulo - SP
}

March 1, 2022

\begin{abstract}
Headwater basins are central for meeting water management and, in humid tropical areas, essential to understand the baseflow, the discharge component that maintains water availability during the dry season, and the stormflow generated from recurrent convective clouds that can lead to flash floods. We measured field data in a typical headwater basin and four sub-basins, in subtropical climate region of Serra da Mantiqueira/South-East Brazil, with a multi-instrument hydrometeorological set (precipitation, streamflow, baseflow, stormflow, soil moisture SM, water table depth WTD), towards providing regional data, to our knowledge, hitherto non-existent, on hydrological response patterns, and variation of stormflow generation with boundary conditions and scale. Precipitation recovered in September and peaked in January concurrently with streamflow. Baseflow responded for most of the streamflow during the dry season and about half in the wettest months, and peaked ahead in March, highly covariated with WTD. In contrast, SM described a longer yearly memory, that recovered 3 months earlier than streamflow, and depleted 2 months latter in March. The monthly scale stormflow responded significantly to rainfall although with low predictability. At the event scale, revealling patterns for all basins showed thresholds of precipitation ([?] $10 \mathrm{~mm}$ ), SM ([?]45\% to 57\%) and WTD [?]135 cm, below which stormflow was modest. The event stormflow coeficient (eSC) reached up a maximum of $25 \%$, albeit with large variance and little seasonality of the median. Estimates of eSC with double mass and SM thresholds showed pronounced spatial and temporal differences (3.2 to $9.6 \%$ in drier conditions and 7.7 to $15.4 \%$ wetter conditions). Mean streamflow and runoff coefficient were quite lower at the main basin (21\% compared to about [?] $32 \%$ between sub-basins), where there possibly exists groundwater flux exportation, that discharge on a larger spatial scale, by water exiting the basin without passing through the surface outlet.
\end{abstract}

\section{Hosted file}

Chittolina_RR_Paper_vSubmission.docx available at https://authorea.com/users/462962/articles/ 558219-hydrological-response-of-a-headwater-catchment-in-southeastern-brazil-part-ipatterns-of-rainfall-runoff-and-stormflow

\section{Hosted file}

Chittolina_RR_FiguresTables_vSubmission.docx available at https://authorea.com/users/462962/ articles/558219-hydrological-response-of-a-headwater-catchment-in-southeastern-brazilpart-i-patterns-of-rainfall-runoff-and-stormflow 